\title{
Analysis quality characteristics of virgin coconut oil (VCO): comparisons with cooking coconut oil (CCO)
}

\author{
${ }^{1}$ STIKes Karya Putra Bangsa Tulungagung, Indonesia \\ a aynatalia16@gmail.com \\ b dewi.trinatalia25@gmail.com \\ c fendrilucky2@gmail.com \\ dikaani456@gmail.com \\ e indratarigan92@gmail.com * \\ * corresponding author
}

Ayu Natalia ${ }^{1 \mathrm{a}}$,Dewi Natalia $\mathbf{R}^{1 \mathrm{~b}}$, Fendri Lukmanto ${ }^{1 \mathrm{c}}$, Ika Ani ${ }^{1 \mathrm{~d}}$, Indra Lasmana Tarigan ${ }^{1 \mathrm{e}^{*}}$

\begin{tabular}{l}
\hline ARTICLE INFO \\
\hline Article history: \\
Received date: \\
April 10th 2019 \\
Revised date: \\
April 19th 2019 \\
Accepted: \\
April 29th 2019 \\
Published: \\
Mei $1^{\text {st } 2019}$ \\
\hline
\end{tabular}

Keywords:

VCO

CCO

Physical Parameters

Chemical Parameters

\begin{abstract}
This study aims to examine the quality of cooking coconut oil (CCO) and virgin coconut oil (VCO). The analysis was carried out as a physical parameter test including organoleptic and density while the chemical parameter test was: free fatty acid (FFA) peroxide number and test of saponification number. The sample oil used comes from coconut oil made traditionally by virgin coconut oil or commonly abbreviated as VCO, which is coconut oil which passes through a different extraction process with ordinary coconut oil so it is believed to have higher quality and provide more benefits. Samples derived from coconut oil traditionally processed in Beji Village, Boyolangu District with the brand "MALIKA". It was found that both oils had relatively the same physical parameters, the difference in density on VCO and CCO: $0.88 \mathrm{~g} / \mathrm{ml}$ and $0.82 \mathrm{~g} / \mathrm{ml}$. As for the chemical parameters of free fatty acids, peroxide numbers, and saponification numbers of the VCO and CCO comparisons: 0.165: 0.207; 0.54: 0.68; 203: 321 , so that the overall VCO has good quality, while CCO has an unfavorable saponification number.
\end{abstract}

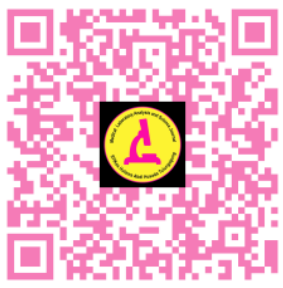

This is an open access article under the CC-BY-SA license

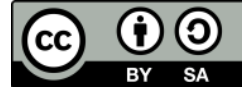

\section{INTRODUCTION}

Coconut oil is a product that produced from copra which is processed by drying coconut which taken directly from the fresh coconut by wet method (wet coconut process) by either centrifugation, fermentation, enzymatic, $\mathrm{pH}$ method, or any of these combinations to destabilizie the coconut milk emulsion without the drying process. ${ }^{1}, \underline{2}$ In contrass, dry processing oil is obtained by either pressing or using a solvent. $\stackrel{\text { The }}{\text { Tain }}$ difference between the two processes is that the oil produced from dry processing with copra raw material is not ready yet to be consumed because the oil produced is still in the form of crude coconut oil (CCO).,,$\underline{3}$ Coarse of coconut oil has a relatively high level of free fatty acids. Crude coconut oil, somehow, that it is suitable for consumption even has to go through several stages of the process, among others: refining, bleaching and deodorizing. - The final product of coconut oils has to evaluate with the following characteristics: yellowish, tasteless and odorless, while coconut oil that is a wet process, can be directly consumed without undergoing a refining process. ${ }^{4}$ In principle, the wet 
processing of coconut oil is through the stage of making coconut milk. Wet processing involves three stages: extracting coconut milk, separating coconut milk into cream and skim, and breaking down the coconut milk emulsion to produce oil. Wet processing of coconut oil can produce the final product in the form of coconut oil known as virgin oil, virgin coconut oil or VCO.., 3

Along with the development of information and communication technology, people easily to find any information and benefits from VCO for human health. $\frac{5}{-W e}$ can find several VCO brands which is produced on the market, one of which is VCO produced under the brand "MALIKA" (processing using gradual heating), revealing the cure of various types of diseases. VCO is known to have benefits in overcoming several types of diseases, including: narrowing of blood vessels, canker sores, coughs, colds, hepatitis, diabetes, gout, high cholesterol, cramps, calcification, ulcers, pain in the knee, heart, ringworm, vaginal discharge, hemorrhoid tonsils, being overweight and HIV. $\underline{6}$ The VCO standard of the APCC is still a temporary standard, therefore, national standards include: $0.3 \%$ maximum free fatty acids, peroxide numbers maximally $1 \mathrm{meg} / \mathrm{kg}$ of oil and a maximum saponification number of $0.2 \%$, but the ideal characteristics of VCO are: color clear (measurement with Lovi-bond Tintometer: Yellow 1 and Red 0.1) is a reference in measuring the quality of the oil. ${ }^{?}$

Besides the benefits of VCO, there are several processing methods to obtain high-quality of VCO. Because there are many consumers who want to get the various benefits of VCO for health, VCO process will be found in almost every province in Indonesia, both at household and farmer groups, so that young VCO products are obtained.. While there are still many views that state that coconut oil is harmful to health. In addition to the opinion that heart and blood vessel diseases are a result of the consumption of fat / fatty oil, also due to negative issues spread by the American Soybean Association (ASA), $\stackrel{9}{ }$ which states that coconut oil contains saturated fatty acids which can form plaques on the walls of blood vessels causing coronary heart disease, hypercholesterolemia, and hypertension. $\frac{10}{}$ Various scientific studies in recent years prove that virgin coconut oil (VCO) contains saturated fatty acids that are unique and different from saturated fatty acids in general. Saturated fatty acids in coconut oil are medium and short chain saturated fatty acids. -11 Today the role of coconut oil as a component of the drug begins to increase compared to other vegetable oils. The East Java Provincial Plantation Office launched, Tulungagung as one of the East Java coconut producer centers was chosen as the place for producing VCO and CCO, one of them with the brand "MALIKA". Precisely in Pagersari Village, Kalidawir District, Tulungagung Regency (East Java Plantation Service, 2014). The threshold of oil is a good free fatty acid of $0.3 \%$, peroxide is maximally $1 \mathrm{meq} / \mathrm{kg}$ of oil and saponification number is $0.2 \%$, but the ideal characteristics of VCO are clear color (measurement with Lovibond Tintometer: Yellow 1 and Red 0.1).

Based on the data that we have been explained, a study of the quality of coconut oil from VCO and CCO was carried out with the aim of research to analyze qualitative VCO and CCO physically and chemically. Measurements in physics with organoleptic and density while chemically by testing free fatty acids, peroxide numbers, and saponification tests. Cooking oil quality standards have been formulated and determined by the National Standardization Agency (BSN), namely SNI 01-3741-2002, this SNI is a revision of SNI 01-3741-1995.

\section{MATERIALS AND METHODS}

The research is a descriptive survey that describes the quality of oil from the coconut fruit, in the form of VCO and CCO products using physical and chemical parameter test. Sampling is done with experimental research techniques. The analysis technique used is descriptive statistics which describe or give an overview of the object under study through sample or population data, without analyzing then give conclusions that apply to the 
public. We purchased VCO and CCO which is namely, "MALIKA" that isa brand of VCO and CCO are produce from Beji village, Boyolangu District. This research was conduct in December 2018, and the research location was in Beji Village, Boyolangu District. All of the processes, experiment, and data analysis were carried out at the chemical Laboratory of STIKes Karya Putra Bangsa Tulungagung. We have used several chemical materials, $\mathrm{KOH}(89 \%, \mathrm{MERCK}), \mathrm{Na}_{2} \mathrm{~S}_{2} \mathrm{O}_{3}(98 \%, \mathrm{MERCK}), \mathrm{HCl}(37 \%, \mathrm{MERCK})$, and Phenolptalein indicator. Some instrument that we use, a set of titration equipment, pipet, Erlenmeyer, and Pycnometer (Sigma-Aldrich).

\section{Physics Parameters:}

The measurement of physical parameters was carried out organoleptically and density test based then compare with $\mathrm{SNI}, \underline{11}$ both samples VCO and $\mathrm{CCO}$, were tested using a color route tool for organoleptic test and density test using weighing glass tools and analytic balance. Measurement and data collecting was done 3 times (triple) to avoid data errors and get consistent results. The color of palm cooking oil is determined by the presence of pigments that remain after the bleaching process. It is because the fatty acids and glycerides are colorless. Orange or yellow due to the presence of carotene pigments which are soluble in oil. The smell and flavor in oil are naturally available also due to the presence of short chain fatty acids that effect of oil damage. While the typical smell of palm oil is due to the beta-ionone compound. The melting point of palm oil is in the temperature range because palm oil contains several kinds of fatty acids which have different melting points. $\underline{12}$

\section{Chemical Parameter:}

The measurement of chemical parameters was carried out by three tests which that free fatty acid test, peroxide number test, and saponification test which is modified by the previous study.., 13 We conduct of free fatty acids by titration iodometry to determine the number of free fatty acids with the formula calculation. Moreover, to determine the peroxide number, we conduct a test by titration and using $\mathrm{Na}_{2} \mathrm{~S}_{2} \mathrm{O}_{3} 0.1 \mathrm{~N}$ as a standard solution. To complete of the chemical properties data, we conduct the saponification number by following two stages, which is $\mathrm{KOH}$ standardization by titration using $0.5 \mathrm{~N} \mathrm{HCl}$ and the second determines the saponification number using a set of reflux then titrated using $\mathrm{HCl} 0.1 \mathrm{~N}$.

\section{Free Fatty Acids:}

Two grams of oil sample was weighed and put in Erlenmeyer flask. Then $50 \mathrm{ml}$ of alcohol was added 95\% neutral. 3-5 drops of fenoftalein indicator are added to the solution and titrated with a standard $0.1 \mathrm{~N} \mathrm{KOH} .13$ The end of the titration is obtained if a pink color is formed that does not disappear for 0.5 minutes.

$$
\begin{gathered}
\% \mathrm{FFA}=\frac{\mathrm{ml} \mathrm{KOH} \times \mathrm{N} \mathrm{KOH} \times \mathrm{MW} \text { Oils }}{\mathrm{m} \times 10} \\
\mathrm{~m}=\text { weight of oil }(\mathrm{gr}) ; \mathrm{MW} \text { : Moleculer Weight (gr) }
\end{gathered}
$$

Acid Number:

10 grams of $\mathrm{VCO}$ and CCO, then added $50 \mathrm{~mL}$ of $95 \%$ neutral alcohol, then heated in a water bath for +10 minutes while stirring. The solution was titrated with $\mathrm{KOH}$ $0.05 \mathrm{~N}$ with 3-5 drops of fenoftalein indicator in alcohol, until it was exactly pink. ${ }^{-14}$

$$
\text { Acid Number }=\frac{A \times N \times 56,1}{\text { Weight sample }}
$$

$\mathrm{A}=$ The number of $\mathrm{ml}$ of $\mathrm{KOH}$ for titration; $\mathrm{N}=$ Normality of $\mathrm{KOH} ; 56,1=\mathrm{MW}$ of $\mathrm{KOH}$ 
Peroxide Number:

$10 \mathrm{~g}$ of VCO and CCO is weighed and then put in a $250 \mathrm{ml}$ closed Erlenmeyer flask. Subsequently, $12 \mathrm{ml}$ chloroform and $18 \mathrm{ml}$ glacial acidic acid were added to the flask. The solution is shaken out until all the ingredients are dissolved. After all the ingredients are mixed, $0.5 \mathrm{~mL}$ of saturated solution $\mathrm{KI}$ is added. For 1 minute the solution mixture was left to stand while still being shaken out, then added $30 \mathrm{~mL}$ of distilled water. Next, into the mixture, the $0.5 \mathrm{ml} 1 \%$ starch is added and immediately titrated with $\mathrm{Na}_{2} \mathrm{~S}_{2} \mathrm{O}_{3} 0.1 \mathrm{~N}$ until the solution changes color from blue to blue and begins to disappear. Determination is done by repeating twice. $\frac{15}{5}$

$$
\text { Peroxide Number }=\frac{\left(\mathrm{V}_{0}-\mathrm{V}_{1}\right) \times \mathrm{N} \mathrm{Na}_{2} \mathrm{~S}_{2} \mathrm{O}_{3} \times 1000}{\text { Weight sample }}
$$

$\mathrm{V}_{0}=$ Volume of titration $\mathrm{Na}_{2} \mathrm{~S}_{2} \mathrm{O}_{3}$ of sample; $\mathrm{V}_{1}=$ Volume of titration $\mathrm{Na}_{2} \mathrm{~S}_{2} \mathrm{O}_{3}$ of blank; $\mathrm{N}=$ Normality of $\mathrm{Na}_{2} \mathrm{~S}_{2} \mathrm{O}_{3}$

\section{RESULTS AND DISCUSSION \\ Pysical Analysis of VCO and CCO}

In the analysis of the physical parameters of oil, we compared two oil samples, VCO and CCO then analyse whether the oils has good quality standard criteria or not. The results of the analysis can be seen in table 1.

Table 1. Physical Parameter Analysis of VCO and CCO Oils

\begin{tabular}{|c|c|c|c|c|}
\hline \multirow{2}{*}{ No. } & \multirow{2}{*}{ Parameters } & \multicolumn{2}{|c|}{ Oil } & \multirow{2}{*}{ Criteria } \\
\hline & & VCO & CCO & \\
\hline \multirow[t]{3}{*}{1.} & Organoleptic & & & \\
\hline & Color & Snow/ Clean Color & Khaki & Normal \\
\hline & Smell & Coconut & Coconut & Normal \\
\hline 2. & Density & $0,88 \mathrm{~g} / \mathrm{ml}$ & $0,82 \mathrm{~g} / \mathrm{ml}$ & Intermediate \\
\hline
\end{tabular}

The organoleptic parameters were analyzed for the color and smell of both VCO and CCO oils. Both are Khaki colorless and compared to the standard oil criteria, then both are normal color. To support of the physical parameter analysis data, the oil density test was carried out using pycnometer, then we found that $0,88 \mathrm{~g} / \mathrm{ml}$, it seems that good oil has a density value ranging from $0.86-0.91 \mathrm{~g} / \mathrm{ml}, \underline{16}$ so it can be concluded that the VCO density value, 0.88 is in the standard value and is quite good if we compared to the CCO which has a density of $0.82 \mathrm{~g} / \mathrm{ml}$.

\section{Chemical Analysis of VCO and CCO}

In analyzing oil quality with chemical parameters there are many indicators that can be analyzed. In this study the three indicators used were free fatty acids, peroxide numbers, and saponification numbers. Good oil has a free fatty acid value of $<0.5 \%$, peroxide number $<10 \%\left(\leq 10\right.$ meek $\mathrm{O}_{2} / \mathrm{kg}$ ) and saponification number $>200 . \underline{16}$ Acid numbers are a measure of the amount of free fatty acids. Free fatty acids are contained in oil or fat, the amount will continue to grow during the processing and storage. The existence of free fat is usually used as an initial indicator of oil damage.

Table 2. Chemical Parameter Analysis of VCO and CCO

\begin{tabular}{|c|c|c|c|}
\hline & Danamatan & & \\
\hline No. & rarameters & VCO & $\mathrm{CCO}$ \\
\hline
\end{tabular}




\begin{tabular}{llcccc} 
1. & Free Fatty Acid & 0.165 & 0.207 & Good & Good \\
\hline 2. & Peroxide Number & 0.54 & 0.68 & Good & Good \\
\hline 3. & Saponification point & 203 & 321 & Good & Good \\
\hline
\end{tabular}

Free fatty acids are fatty acids that have been released from triglycerides because of the hydrolysis process. These free fatty acids can be oxidized automatically or by an enzyme called lipoxygenase. Oxidation especially occurs in unsaturated fatty acids, namely oleic acid, linoleic acid, and linolenic acid which are mostly contained in fat or oil. In the hydrolysis reaction, the oil will be converted into free fatty acids and glycerol. The final result of this reaction is rancidity of hydrolysis which produces rancid flavor and odor in oil. 17 Based on the results of the analysis showed that the fatty acid number of VCO 0.165 and CCO, 0.207 which means there are in the standard of good oil. Both are below the maximum value of free fatty acids, so they are still in the standard of good consumption. $\frac{18}{18}$

Besides analyzing the number of free fatty acids, we also analyzed the peroxide values of VCO and CCO. Peroxide is the most important value for determining the degree of damage to oil or fat. Unsaturated fatty acids can bind oxygen to their double bonds to form peroxide. This peroxide can be determined by iodometry method. Oils that contain unsaturated fatty acids can be oxidized by oxygen which produces a peroxide compound. The high peroxide number indicates damage to the oil and oil will soon experience rancidity. High peroxide numbers may be caused by oxidation in some fatty acids, especially unsaturated fatty acids. The small number of peroxides produced shows that the quality of the oil is good, because if the amount of peroxide in the oil increases, the oil will quickly become rancid. VCO and CCO peroxide numbers as shown in table 2 show that the quality is good, smaller than the SNI standard so that both have good peroxide numbers for consumption. $\underline{16}, \underline{19}$

The third indicator analyzed in this chemical parameter is saponification. The saponification number is the amount of alkali needed to soap a number of oil samples. The amount of saponification depends on the molecular weight of the oil. Oils that have low molecular weight will have a high saponification number than oils that have a high molecular weight. $\frac{18}{B}$ Based on the results of $\mathrm{VCO}$ and $\mathrm{CCO}$ oil saponification analysis, the value of saponification value $\mathrm{VCO}=203$ while $\mathrm{CCO}=302$. The saponification reaction occurs when fat is heated in the presence of alkali (sodium hydroxide) which can cause glycerine esters to be converted to salt and glycerin. This long-chain fatty acid salt is called soap so that the reaction is called a saponification reaction. ${ }^{19}$ The saponification rate is getting bigger, which is an indicator that the oil produced is getting better. Besides coconut oil produced without going through a heating process so that the fatty acid content tends not to change. $\underline{20}$ So it can be concluded that VCO and $\mathrm{CCO}$ have high saponification values and are good for consumption.

Virgin Coconut Oil (VCO) is a product that very popular with consumers, since 2002. This phenomenon due to the amount of information obtained through training, print media, electronics, and the internet, about the various benefits of VCO for health. Some consumers who consume VCO produced by processing use gradual heating, revealing healing from various types of diseases. ${ }^{9}$ Their testimony of the benefits of VCO in overcoming several types of diseases, including: narrowing of blood vessels, canker sores, coughs, colds, hepatitis, diabetes, gout, high cholesterol, cramps, calcification, ulcers, pain in the knee, heart, ringworm, vaginal discharge, and haemorrhoid. 18,20 Moreover, VCO was using for diet therapy directly, and VCO is consumed while for CCO is used for cooking oil for in identifying quality21. Our result shows that, characterization of both VCO and CCO using physical and chemical parameters, the physical parameters: based on the results of research on VCO and CCO materials from both samples meet the physical requirements in accordance with the standard namely organoleptic covering the 
color of VCO snown and CCO khaki and VCO and CCO typical odors coconut and to test its density in the results of the VCO study of 0.88 and $0.82 \mathrm{CCO}$ with the standard according to SNI VCO $0.900-0.913$ and CCO 0.900 . While for the chemical parameters which are the results of the identification of the quality of VCO and CCO as a reinforcement, chemical parameters are tested. Tests included the levels of free fatty acids of 0.165 peroxide number VCO 0.54 and CCO 0.68 saponification of VCO 203 and CCO 321.

\section{CONCLUSIONS}

VCO and CCO have good physical parameter values, are colorless and odorless. Then, their density values are relative to the standard oil values in general. VCO and CCO have free fatty acid numbers 0.16 and 2.07 smaller than SNI standard 0.3 and are still in good criteria. VCO and CCO have peroxide numbers 0.54 and 0.68 which are smaller than the SNI standard of $10 \%$ and are still in good criteria. VCO and CCO have good saponification numbers, 203 and 301 which are relatively high in value. Overall CCO has a better parameter value than VCO.

\section{REFERENCES}

1. Ghani, N. A. A., Channip, A. A., Hwee Hwa, P. C., Ja'afar, F., J., Yasin, H. M., \& Usman, A. (2018). Physicochemical properties, antioxidant capacities, and metal contents of virgin coconut oil produced by wet and dry processes. Journal of Wiley Food Science and Nutrition, 6(1), 1298-1306. DOI: http://doi.org/10.1002/fsn3.671

2. Eyres, L., Eyres, M.F., Chisholm, A., \& Brown, R.C. (2016). Coconut oil consumption and cardiovascular risk factors in humans. Nutrition Reviews, 74(4), 267-280. DOI: http://doi.orf/10.1093/nutrit/nuw002

3. Orsavova, J., Misurcova, L., Ambrozova, J. V., Vicha, R. \& Mlcek, J. (2015). Fatty Acids Composition of Vegetable Oils and Its Contribution to Dietary Energy Intake and Dependence of Cardiovascular Mortality on Dietary Intake of Fatty Acids. International Journal of Molecular Sciences, 16(1). 12871-12890. DOI: http://doi.org./10.3390/ijms160612871

4. Setiaji, B., \& Prayugo, S. (2006). Membuat VCO Berkualitas Tinggi (2nd Ed), Penerbit Penebar Swadaya, Jakarta

5. Widiyanti, R.A. (2015). Pemanfaatan Kelapa Menjadi VCO (Virgin Coconut Oil) Sebagai Antibiotik Kesehatan Dalam Upaya Mendukung Visi Indonesia Sehat 2015. Prosiding Seminar Nasional Pendidikan Biologi 2015, Universitas Muhammadiyah Malang, 1(1), 577-584. DOI: http://dx.doi.org/10.20473/amnt.v2i2.2018.205-211

6. Taufik, M., \& Seftiono, H. (2018). Karakteristik Fisik dan Kimia Minyak Goreng Sawit Hasil Proses Penggorengan dengan Metode Deep-Fat Frying. Jurnal Teknologi Universitas Muhammadiyah Jakarta, 10(2), 123-130. DOI: https://dx.doi.org/10.24853/jurtek.10.2.123-130

7. Novilla, A., Nursidika, P., \& Mahargyani, W. (2017). Komposisi Asam Lemak Minyak Kelapa Murni (Virgin Coconut Oil) yang Berpotensi sebagai Anti Kandidiasis. Jurnal Kimia dan Pendidikan (EduChemia), 2(2). 161-173. DOI:

http://doi.org/10.30870/educhemia.v2i2.1447

8. Badan Standard Nasional Indonesia. SNI 7709. (2013). Syarat Mutu Minyak Goreng Kelapa Sawit. Dewan Standar Nasional: Jakarta

9. Ebere, E. C., Amarachukwu, I. E., Wirnkor, V. A., \& Ngozi, E. P. (2017). Physicochemical Parameter of Palm Oil and Soil from Ihube Community, Okigwe, Imo State Nigeria. International Letters of Natural Sciences, 62(1), 35-43. DOI: http://doi.org/10.18052/www.scipress.com/ILNS.62.35

10. Silalahi, R.L.R., Sari, D.P., \& Dewi, I.A. (2017). Testing of Free Fatty Acid (FFA) and Colour for Controlling the Quality of Cooking Oil Produced by PT. XYZ. Jurnal 


Teknologi dan Manajemen Agroindustri, 6(1), 41-50. DOI:
https://doi.org/10.21776/ub.industria.2017.006.01.6

11. Sopianti, D.S., Herlina, Saputra, H.T. (2017). Penetapan Kadar Asam Lemak Bebas Pada Minyak Goreng. Kementrian RISTEK Journal Katalisator Kopertis Wilayah X, 2(2), 100-105. DOI: http://doi.org/10.22216/jk.v2i2.2408

12. Pangestuti, D.R, \& Rohmawati, S. (2018). Peroxide Content in Cooking Oil Used By Fritter Traders in Tembalang Subdistrict Semarang City. Amerta Nutrition, Airlangga University, 2(2), 205-211. DOI: http://doi.org/10.2473/amnt.v2i2.2018.205-211

13. IImi, I.M.B, Khomsan A, Marliyati.S.A. (2015). Kualitas Minyak Goreng dan Produk Gorengan Selama Penggorengan di Rumah Tangga Indonesia. Jurnal Aplikasi Teknologi Pangan. Jurnal Aplikasi Teknologi Pangan, 4(2), 61-65. DOI: http://doi.org/10.17728/jatp.2015.12.

14. Kenechi, N. O., Felix, A., Linus, C., \& Kayode, A. (2017). Analysis on the Physicochemical Properties of Palm Oil Within Isialangwa Local Government Area of Abia State, Nigeria. International Journal of Bioorganic Chemistry, 2(4), 159-162. DOI: http://doi.org/10.11648/j.ijbc.20170204.11

15. Maochong, L. (2014). Research on Edible Oil Quality and Safety System. International Conference on Mechatronics, Control and Electronic Engineering, 1(1), 732-736. DOI: https://doi.org/10.2991/mce-14.2014.158DO

16. Naser S., Mahmoudian, M.H., Yari, A.R., Molaghen.S., \& Mahmoodian.Z. (2018). Evaluation of Peroxide Value and Acid Number of Edible Oils Consumed in the Sandwich and Fast Food Shops of Qom, Iran in 2016. Archives of Hygiene Sciences, 7(2), 91-97. DOI: http://doi.org/10.29252/ArchHygSci.7.2.91

17. Saikhwan, P., Nuchnet,C., Wanakayont,W., \& Suksa-nga, A. (2016). Extraction of Coconut Oil from Coconut Milk Foulants Using Enzyme. MATEC Web of Conferences (ICCFE), 62(1), 1-5. DOI: https://doi.org/10.1051/matecconf/20166202008

18. Nainggolan, B., Susanti, N., \& Juniar, A. (2016). Uji Kelayakan Minyak Goreng Curah dan Kemasan yang Digunakan Menggoreng Secara Berulang. Jurnal Pendidikan Kimia, 8(1), 45-57. DOI: http://doi.org/10.24114/JPKIM.V8I1.4424

19. Parkinson, L., \& Cicerale, S. (2016). The Health Benefiting Mechanisms of Virgin Olive Oil Phenolic Compounds. Molecules, 21(12),1-12. DOI: http://dx.doi.org/10.3390/molecules21121734

20. Siddique, B.M., Muhamad, I.I., Ahmad, A., Ayob, A., Ibrahim, M.A., Omar, M.AK. (2015). Effect of frying on the rheological and chemical properties of palm oil and its blends. J Food Sci Technol, 52(2), 1444-1542. DOI: http://doi.org/10.1007/s13197$\underline{013-1124-6}$ 